\title{
The Shift of Acehnese Language in Pulau Kampai Community North Sumatra
}

\author{
Chairuddin \\ Samudra University, Langsa \\ Email: chairyfkip@unsam.ac.id
}

\begin{abstract}
This study deals with "The Shift of Acehnese Language in Pulau Kampai Community". The aims of this research are: (1) to obtain the reasons of language shifting that has happened in Pulau Kampai, and (2) to find out what factors that caused shifting of Acehnese language in Pulau Kampai. This research used descriptive qualitative method. The subject of research is the second generation of Acehnese community in Pulau Kampai. The researcher found that the shifting pattern of Acehnese language among Acehnese community in Pulau Kampai is bilingual subordinate patterns that exist in the second stage. The Acehnese community (the second generation) still uses Acehnese language predominantly but there are some new words that come from other languages that are used to replace some words in Acehnese. The shifting of Acehnese language happened due to four interconnected, i.e. (1). Migration (Acehnese community in Pulau Kampai is newcomers from the other areas: from Beurenuen, Sigli, Tamiang and Aceh Timur, (2). Number of the speakers (Acehnese community is minority community, (3) Demography, (Location of new area), and (4) Economic factor (a condition that requires Acehnese people to meet or join other workers) causing language shift.
\end{abstract}

Keyword: language shift, Acehnese language, regional language, regional identity

\section{Introduction}

Indonesia is a country whose territory is very wide, and consists of various tribes, with various regional languages, as well as various unequal cultural backgrounds. One of the areas in Indonesia called Aceh has nine regional languages: Gayo, Alas, Tamiang, Aneuk Jamee, Kluet, Singkil, Simeulu, and Balohan languages (Wildan, 2001).

Besides being a means of communication, language also serves as a symbol of regional identity. Generally, people of Aceh introduce themselves to others using Acehnese language so people could easily identify their ethnic identity (Wildan, 2001). This means that in order to maintain their identity Acehnese people must be able to maintain Acehnese language in everyday life in order to prevent the extinction of the language. 
Pulau Kampai is a small island village at Pangkalan Susu Subdistrict of Langkat District, North Sumatra with the total population of 4.200 residents (BPS Kabupaten Langkat 2013). It takes about 3 hours drive from Kota Medan to Pangkalan Susu. Then from Pangkalan Susu to Pulau Kampai people must continue the trip by boat.

Pulau Kampai as a village consists of several multilingual and multiculturalcomunities laden with linguistic phenomena. This is so because their language contact cannot be avoided. The sustainability of a language is determined by several factors such as surrounding and culture. Those factors could make a certain language shift.

The language shift happens when language user selects a new language to replace the previous language. In other words, language shift occurs due to the public certain language switching to another language; in this case, usually the dominant language will exist. Wildan (2001: 68) defines language shift as the change from the habitual use of one language to that of another language.

This condition is in line with what happens in Pulau Kampai where the researcher found that there was Acehnese community speaking Acehnese language with several shifts.

From the preliminary observation, there are several words in Acehnese language that have shifted, such as nicknames of family members; the word " $a p a$ " to call their uncle in Acehnese language, was changed with the word "om" or "pakcik" refering to uncle. This phenomenon has become very interesting to be studied.

\section{Literature Review}

\subsection{Language Shift}

Language shift is a phenomenon of language replacement where by a speech community replace their first language and select a new language to speak in their daily life. According to Romaine (1995: 41) "language shift is a symptom of changes in form and meaning of a foreign language to the emergence of a collective phenomenon, that is, when the community leaving the first language and use another language. These collective symptoms caused by the dynamics of multilingual society with various social aspects in it. In multilingual society, language contact cannot be avoided. Role, position and function of the language led to the choice of language.

Fasold (1984: 213-214) states that language shift is the result of the election of language process in a very long period of time. When a language shift occurs, members of a language community as a group prefer to use a new language that is traditionally used. Kridalaksana (2018: 188) says that language shift is a permanent change in one's language choice as a result of migration. 
Some conditions tend to be related to language shifts. The most basic condition is probably bilingualism. But it should be noted carefully that this bilingual is not the only factor that causes the shift of language. Bilingualism does not necessarily cause language shifts, although this is one of the conditions for the shift of language. The cases of language shift are almost entirely through generation transfer (intergeneration). The point is that language shifts take more than a generation.

\subsection{Patterns of Language Shift}

Fishman (1972) has shown a shift in the language of immigrants in America. The third or fourth descendants of the immigrants are no longer familiar with his mother tongue (First language), and instead there has been a monolingual English (second language). The pattern that Fishman mentions about the shifting language of immigrants in Americais shown below:

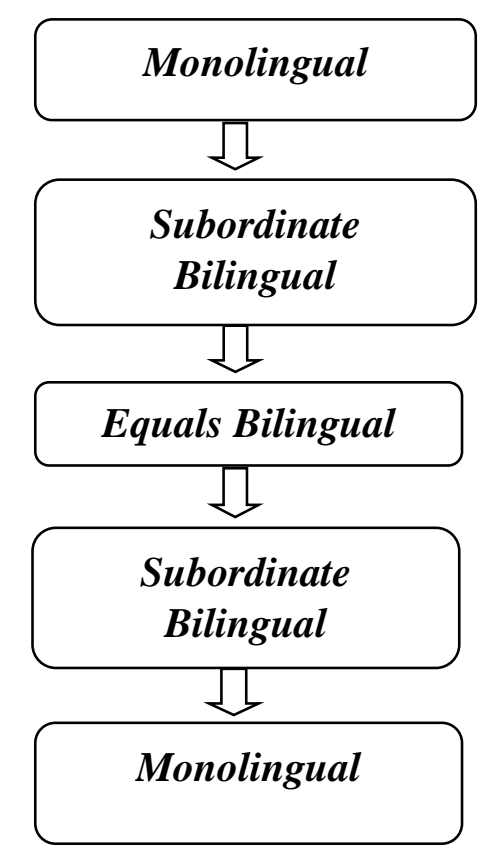

Figure 1. Pattern of Language shift by Fishman (1972)

In the first stage, immigrants use the same language with his mother tongue, then afterwards, as described in the second stage, they have become bilingual subordinates (mother tongue and English) but mother tongue still dominate. After a long time as described in the third stage, their bilingualism is already equal (their English usage is as good as when they use their mother tongue). Furthermore, as depicted in stage four, they begin to become bilingual subordinates but with a much better mastery of English than the mastery of the mother tongue and finally, as in the fifth box, they become monolingual English while the mother tongue they have left behind. 


\subsection{Factors of Language Shift}

There are some factors that cause language shift. The first factor is migration (immigration) and this is in accordance with the statement of Chaer (2004) in which he states that language shift in small communities moves from domain to domain. The general trend for language with "Large" domains invades a smaller language domain. In other words, language shift is not caused by a society occupying a territory, but by an immigrant coming to a territory. Such these cases have occurred in some small areas of England as their industry expanded. Some small languages are the language of locals displaced by the English brought by industrial workers to that small place. The second factor is economic. Economic progress sometimes elevates the position of a language into a language of high economic value (Sumarsono and Partana, 2002: 237). This case can be observed in English. The third factor according to Sumarsono and Partana (2002: 237 ) is school; in this case, it usually happpens in the schools that usually teach foreign languages to their students. This also sometimes causes the shifting position of regional languages. As a result, children are unable to speak the local language. In addition, parents are also reluctant to teach their children the local language because they think their children will have difficulty receiving the lessons given by their teachers who speak Indonesian.

\section{Research Method}

This research uses qualitative descriptive method. Qualitative research is an approach which is also called the investigative approach because usually researchers collected data by way of face to face and interact with the people in the study (McMillan \& Schumacher, 2003). In this research the data obtained are not used in the form of numbers or statistics, but in the form of words (qualitative). Qualitative research obtains data from the natural environment as a direct source of data without data changes and interventions from researchers.

\subsection{Subject of the Research}

In this study, the researcher set 8 subjects as subject of the research. In determining the subject of research, the researcher used purposive sampling. The sample taken as the subject of the study is a sample that meets the predefined criteria. According to Margono (2004: 128) the purposive sampling is the selection of subjects based on certain criteria applied based on the purpose of research. The criteria set by researcher in determining the subject of research are (1). The citizens of Pulau Kampai, (2). Second generation of Acehnese community, (3). Ability to speak Aceh fluently, and (4). Age 1855 years. 


\subsection{Data Collection Procedure}

In collecting data, the researcher used some steps that can be seen in the chart below:

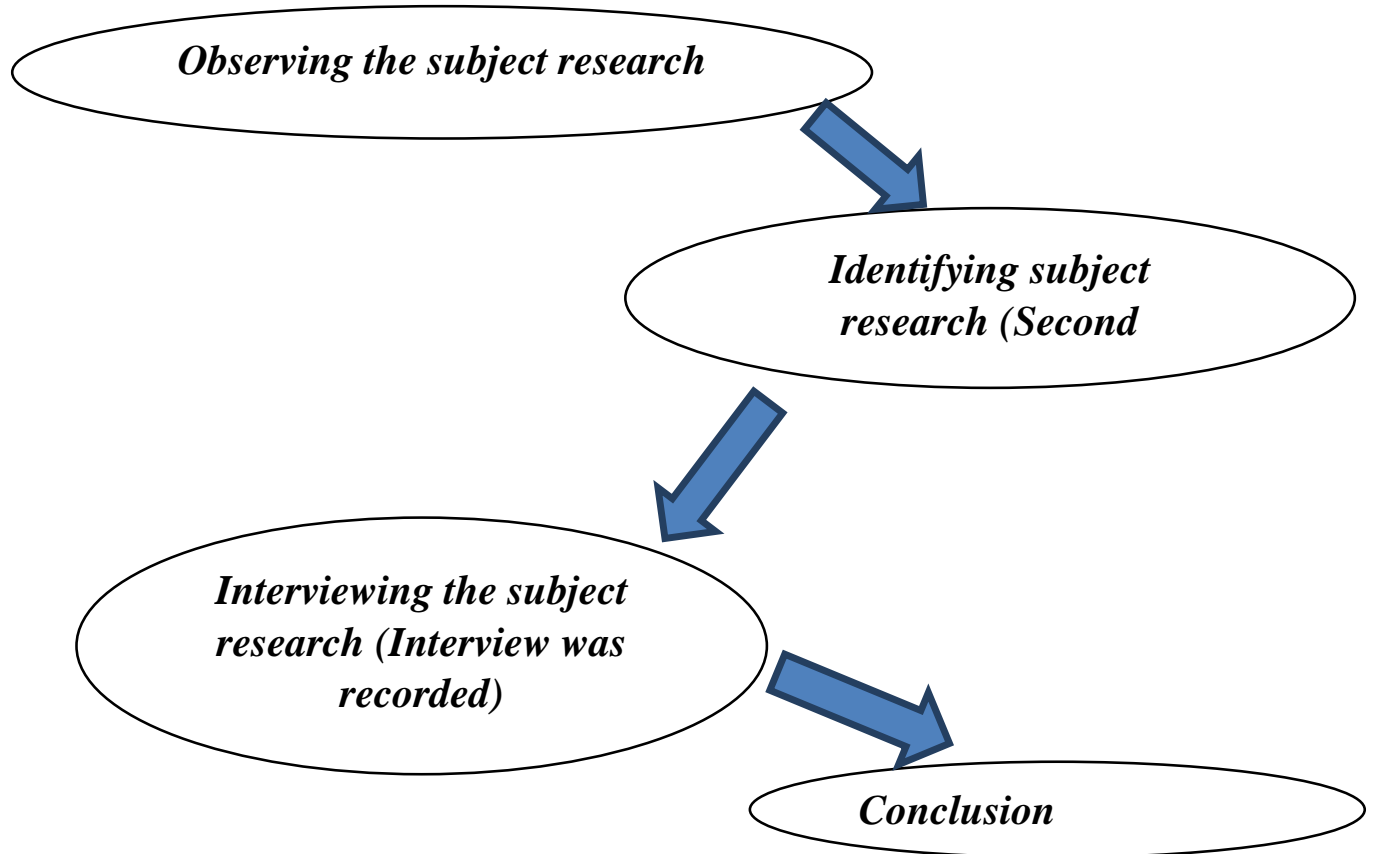

Figure 2. Data Collection Procedure

\subsection{Instrument of the Research}

The data were collected through observation and interview in order to get in-depth data. The researcher described the problem clearly and comprehensively. First the researcher observed social situation of Pulau Kampai: there are places, social life, language and the culture of Pulau Kampai. Then the researcher used voice recorder to record the interview.

\subsection{Data Analysis Procedure}

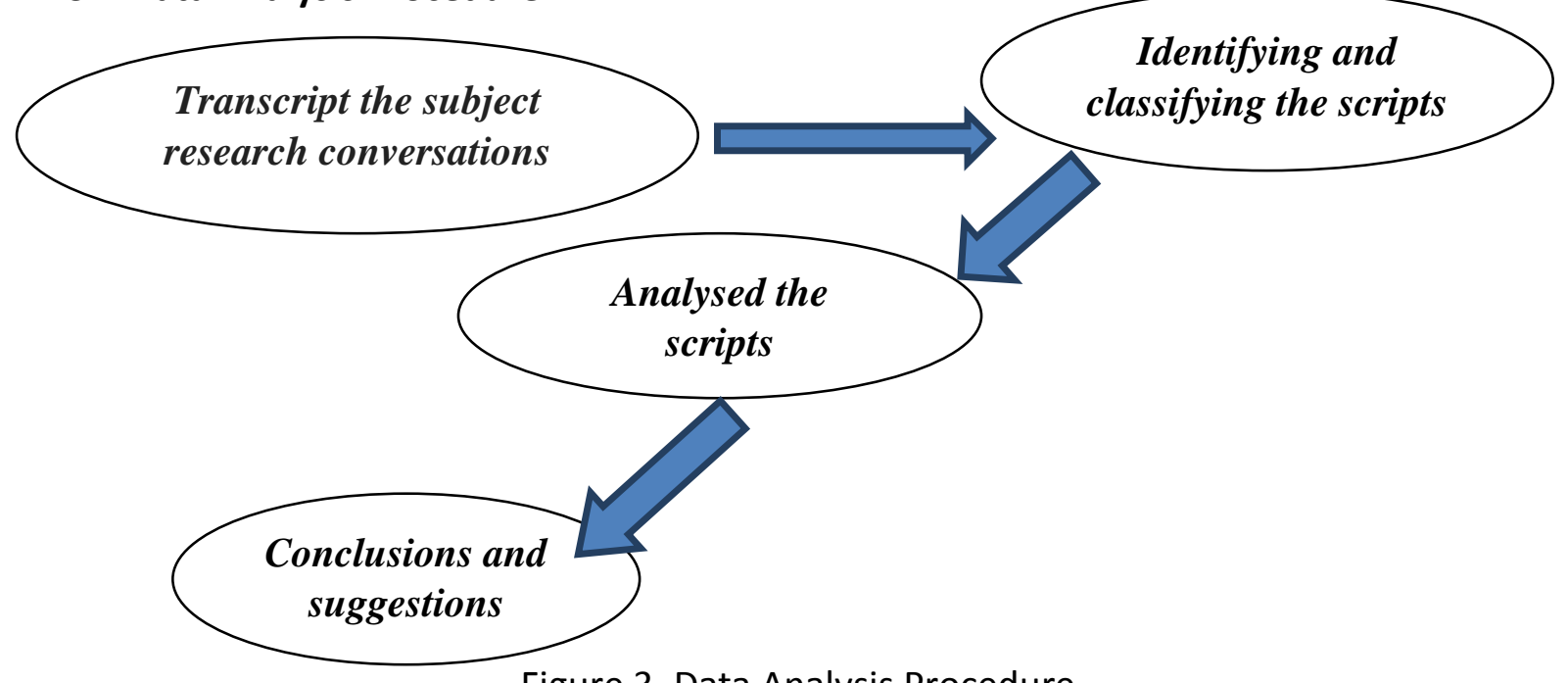

Figure 3. Data Analysis Procedure 
In the data analysis the researcher explained and classified the conversation or dialogue of Acehnese community in Pulau Kampai, identifying the script and choosing words of dialogue in their conversation.

\section{Discussion}

\subsection{The Shifting of Acehnese Language in Pulau Kampai}

The phenomena of language shift occur on the use of words. The Acehnese community still use Acehnese language predominantly but there are some new words that come from other languages that are used to replace some words in Acehnese. From the interview that has been done by the researcher, the researcher found some words used by Acehnese community in Pulau Kampai which have shifted the previous words. The words can be seen in the table below:

Table 1. Names of the Months

\begin{tabular}{c|lll}
\multicolumn{1}{c}{ NO } & ACEHNESE LANGUAGE & INDONESIAN LANGUAGE & ENGLISH \\
\hline & & & \\
1. & Asan-Usén & Januari & January \\
2. & Sapha & Februari & February \\
3. & Molet & Maret & March \\
4. & Adoe Molet & April & April \\
5. & Molet Seuneulheuh & Mei & May \\
6. & Kanduri Boh Kayèe & Juni & June \\
7. & Kanduri Apam & Juli & July \\
8. & Kanduri Bu & Agustus & August \\
9. & Puasa & September & September \\
10. & Uroe Raya & Oktober & October \\
11. & Meuapét & November & November \\
12. & Haji & Desember & December
\end{tabular}

The Acehnese people in Pulau Kampai now use Indonesian language to name the months. Even some of them do not know the names of the months in Acehnesse language. So it can be concluded that there has been a shift in the name of the months in Acehnese language.

Table 2. Names of Days

\begin{tabular}{c|lll} 
NO & ACEHNESE LANGUAGE & \multicolumn{1}{c}{ INDONESIAN LANGUAGE } & \multicolumn{1}{c}{ ENGLISH } \\
\hline 1. & Aleuhad & Minggu & Sunday \\
2. & Seulanyan & Senin & Monday \\
3. & Lasa & Selasa & Tuesday \\
4. & Rabu & Rabu & Wednesday \\
5. & Hameh & Kamis & Thursday \\
6. & Jumeu'at & Jum'at & Friday \\
7. & Sabtu & Sabtu & Saturday
\end{tabular}


The Acehnese people in Pulau Kampainow use Indonesian language to name the days. Even some of them do not know the names of days in Acehness language. So it can be concluded that there has been a shift in the name of the days in Acehnese language.

Table 3. Names of Family Relationship

\begin{tabular}{c|lll} 
NO & \multicolumn{2}{c}{ ACEHNESE LANGUAGE } & \multicolumn{1}{c}{$\begin{array}{c}\text { INDONESIAN } \\
\text { LANGUAGE }\end{array}$} \\
\hline 1. & Ayah, Abi, Abôn, Waléd, Pak & Ayah & Father \\
2. & Mak, Ma, Mi, & Ibu, Bunda & Mother \\
3. & Nèk, Mi Syik & Nenek & Grandmother \\
4. & Aduën & Abang & Elder Brother \\
5. & A & Kakak & Elder Sister \\
6. & Ayah cut, apa cut, & Om & Uncle \\
7. & Mak Wa/pakwa/ayah wa & Wawak / Wo & Wawak (Melayuforms) \\
8. & Keumuën & Keponakan & Nephew \\
9. & Parui & Adik ipar & Younger brother/sister-in- \\
& & & law \\
10. & Biëk & Keturunan & Descent \\
11. & Peurumoh/binoe & Istri & Wife \\
12. & Lakoe & Suami & Husband
\end{tabular}

There are several words of nickname of the family that have undergone a shift. The shift in the use of new words from other languages inserted into the language of Aceh band replace the position of the Aceh word. The bold words (bunda, nenek, abang, kakak, om, pakcik, wawak, wo, keponakan, adik ipar, keturunan, peurumoh and lakoe) are words in the family relationship that have shifted from the original Acehnese language into the form of a word in a new language. Those words are words taken from other languages and used by the Acehnese community in daily life to express about family relationships. The words are taken from Indonesian Language and Malay Language.

Table 4. Words that have been Shifted

\begin{tabular}{|c|c|c|c|}
\hline NO & $\begin{array}{l}\text { ACEHNESE } \\
\text { LANGUAGE }\end{array}$ & $\begin{array}{l}\text { INDONESIAN } \\
\text { LANGUAGE }\end{array}$ & $\begin{array}{c}\text { ACEHNESE SENTENCE FROM } \\
\text { INTERVIEW }\end{array}$ \\
\hline 1. & Piyoh & Istirahat & $\begin{array}{l}\text { Lon istirahat siat, hek that jak ngen } \\
\text { tapak. Jioh rupajih kebon haji jalil. }\end{array}$ \\
\hline 2. & Duek Pakat & Musyawarah & Na musyawarah beklam di meunasah. \\
\hline 3. & Teurasi/Blacan & Terasi, Belacan & Manteng na belacan pak ken? \\
\hline 4. & Meurunoe & Belajar & $\begin{array}{l}\text { Aneuk mit SD sampek SMP hinoe } \\
\text { belajarngaji lheuh asar di meunasah. }\end{array}$ \\
\hline 5. & Lingka & sekitar & Sekitar bineh nyoe mandum krueng. \\
\hline 6. & Lueng & alur & $\begin{array}{l}\text { Hana meen hinoe, kamoe manoe di } \\
\text { alur. }\end{array}$ \\
\hline 7. & Rijang & cepat & $\begin{array}{l}\text { Cepat that uroe, hana ta the- the ka } \\
\text { cot uroe sare. }\end{array}$ \\
\hline
\end{tabular}




\begin{tabular}{|c|c|c|c|}
\hline 8. & Seuleu-ah & sumbangan & $\begin{array}{l}\text { Biasa jih na sumbangan masyarakat } \\
\text { tip- tip moled untuk aneuk yatim. }\end{array}$ \\
\hline 9. & Calamalo & Kacau balau & $\begin{array}{l}\text { Pane na, wate masa konflik kabeh } \\
\text { kacau balau, makajih lon dari madat } \\
\text { pinah kenoe. }\end{array}$ \\
\hline 10. & Padra & sepadan & Jadeh dua jih, sepadan that nyan. \\
\hline 11. & Soh & kosong & $\begin{array}{l}\text { Nyan rumoh ka trep kosong, poe } \\
\text { rumoh ka ji minah. }\end{array}$ \\
\hline 12. & Aneuk nanggroe & penduduk & $\begin{array}{l}\text { Mayoritas penduduk hinoe ureung } \\
\text { tamiang. }\end{array}$ \\
\hline 13. & Bre & lengah & $\begin{array}{l}\text { Hanjeut lengah teuh hinoe, kop lee } \\
\text { engkong , abeh ipajoh pisang } \\
\text { dilampoh. }\end{array}$ \\
\hline 14. & Saweub & sebab & $\begin{array}{l}\text { Sebab ujeun baroe han meutume jak u } \\
\text { lampoh. }\end{array}$ \\
\hline 15. & Sijahtra & Aman & $\begin{array}{l}\text { Hinoe pakek kata Aman menyoe } \\
\text { peugah hana kejadian sapu sapu. }\end{array}$ \\
\hline 16. & Keureuja Udep & Pesta & Pajan pesta aneuk si khairiah ? \\
\hline 17. & $\mathrm{Beb}$ & Tas/ kantong & Teh kantong plastik saboh. \\
\hline 18. & Habeh umu & Meninggal & So meninggal ? \\
\hline 19. & Pisang Wak & Pisang raja & $\begin{array}{l}\text { Na tuha pisang raja dilampoh, padup } \\
\text { ka saboh sisi? }\end{array}$ \\
\hline 20. & Pisang Abee & Pisang kapok & $\begin{array}{l}\text { Pisang kapok nyan menyoe bahasa } \\
\text { tanyoe pisang abee. }\end{array}$ \\
\hline 21. & Gigeh & Rajin & $\begin{array}{l}\text { Kiban han rajin ureung hinoe jak } u \\
\text { kebon, sit nyan but hinoe. }\end{array}$ \\
\hline 22. & Dabeuh & Barang & That le barang neuba go ? \\
\hline 23. & Pueh & Puas & $\begin{array}{l}\text { Han jeut rijang puas, acara ukeu harus } \\
\text { lebeh get. }\end{array}$ \\
\hline 24. & Sirat & Jalan & $\begin{array}{l}\text { Jalan nyoe tembos u kecamatan babo, } \\
\text { tapi jalan nyoe tengoh ipeugot. }\end{array}$ \\
\hline 25. & Liwah ata & Minyak wangi & $\begin{array}{l}\text { Ibuk kheun minyak wangi, tapi ibuk } \\
\text { hana teupu bahasa Aceh jih pu. }\end{array}$ \\
\hline 26. & Lageum & Tanda & $\begin{array}{l}\text { Asai ka meusue kreh kroh hinan tanda } \\
\text { jih katrok engkong. }\end{array}$ \\
\hline 27. & Meukat & Dagang & But ibuk dagang digampong nyoe. \\
\hline 28. & Tekmakatok & $\begin{array}{l}\text { Macam macam } \\
\text { barang }\end{array}$ & Macam macam barang na bacut sapue. \\
\hline 29. & Utoh & $\begin{array}{l}\text { Tukang (Tukang } \\
\text { bangunan) }\end{array}$ & Buet suami ibuk tukang. \\
\hline 30. & Keumbee & Kembar & $\begin{array}{l}\text { Menyoe ureung Aceh keumbee } \\
\text { ikheun, hinoe kembar. }\end{array}$ \\
\hline 31. & Meuseuraya & Gotong royong & $\begin{array}{l}\text { Na gotong royong peugleh kuburan } \\
\text { uroe minggu. }\end{array}$ \\
\hline 32. & Jrat & kuburan & peugleh kuburan uroe minggu. \\
\hline 33. & Kreh & Deres & Deres biasa jih siteungoh uroe sagai. \\
\hline
\end{tabular}


34. Cah Babat

Ureung hinoe rata rata buet geuh babat dilampoh sawet

The table above shows the word shifts in Acehnese language that occur in Pulau Kampai. The researcher got the words from the results of observations and interviews conducted with the Acehnese community in Pulau Kampai. There are 34 words that the researcher has found to have shifted from Acehnese to Indonesian (as shown in the table above).

\subsection{Factors of Language Shift}

Based on the results of the study, the researcher found several factors causing the shifting of Acehnese language in Pulau Kampai community. Some of these factors are presented as follows:

1. Migration. This is in accordance with the statement of Chaer (2004: 142), stating that the factor of language shift concerns the problem of the use of language by a speaker or a group of speakers that occur due to the movement from one community to another speech community. This situation takes place in Pulau Kampai where the Acehnese community of this village is migrants from other areas of Aceh; such as from Beureunun, Sigli and Aceh Timur. These Acehnese communities are actually Acehnese people who speak Acehnese language fluenty. They use Acehnese language in their community, but because Pulau Kampai is a village consisting of several tribes so that the people of Acehnese get a lot of new vocabulary from other languages and applied them to the Acehnese language.

2. Number of Speakers. People of Aceh in Pulau Kampai areminority Acehnese community often interact with other communities; so unconsciously they have made a shift by themselves.

3. Demography. The location of a new area away from the area of origin can be one cause of the shift of language. This is because immigrant groups will hold assimilation with local people to be easily accepted as part of the local community. If Acehnese people come from the same community or region and language, they can still retains the use of the first language. However, to communicate with nongroups or communities, they cannot survive to use their first language. The result arethey have learned to use the language of the locals to make it easier for them to perform various social activities.

4. Economy. The majority of Pulau Kampai's livelihoods are fishermen and trading. Some of them work as producers of the shrimp or fish paste condiment (belacan). Work factor requires them to meet or join other workers causing a shifting of language.

\section{Conclusion}

Language shift is defined as replacement of a language by another language gradually due to the occurrence of language contact. Due to various things the language can lead the shifting. The shifting of Acehnese language has happened in Acehnese community of Pulau Kampaiwith shifting patterns. The Acehnese still speak their own language but 
with different dialects and vocabularies. There are four factors that caused the shifting of Acehnese language in Pulau Kampai community, those are migration, Number of the speakers, demography, and economic factors. The four factors are interconnected causing the language shift move constantly. The local language is the identity of an area, so it can be said that people who cannot speak using their own local languages have no identity.

\section{References}

Chaer, Abdul. (2010). Linguistik Umum. Jakarta: PT. Rineka Cipta.

Fasold, R. (1984). The Sosiolinguistics of Society. New York: Basil Blackwell Inc.

Fishman, Joshua, A. (1972). The Sosiology of Language. Rowley: Newbury House.

Margono. (2004). Metodologi Penelitian Pendidikan. Jakarta: Rineka Cipta.

Mcmillan, James H \& Sally Schumacher. (2003). Research in Education. New Jersey: Pearson.

Romaine, Suzzane. (1989). Billingualism. Oxford: Basil Blackwell.

Sumarsono dan Paina Partana. (2004). Sosiolinguistik. Yogyakarta: Sabda.

Wildan. (2001). Tata Bahasa Aceh. Banda Aceh: Global Educational Consultant Institute (GEUCl) 